\title{
Pengaruh Pelatihan Terhadap Peningkatan Produktivitas Kerja Karyawan PT. Raya Sugarindo Inti Tasikmalaya
}

\author{
Gugum Gumilar \\ Universitas Siliwangi Tasikmalaya \\ Jalan Siliwangi No.24, Kahuripan, Tawang, Kahuripan, Tawang, Tasikmalaya, Jawa Barat 46115 \\ Email: gugumgumilar@unsil.ac.id
}

\begin{tabular}{c}
\hline Artikel Info \\
\hline Received: \\
25 Februari 2018 \\
Revised: \\
8 Maret 2018, \\
Accepted: \\
25 Maret 2018 \\
\hline
\end{tabular}

\begin{abstract}
ABSTRAK
Penelitian ini bertujuan untuk menganalalisis pengaruh pelatihan terhadap peningkatan produktivitas kerja karyawan, dan hambatan- hambatan yang dihadapi oleh PT. Raya Sugarindo Inti Tasikmalaya dalam menyelenggarakan pelatihan dan cara mengatasinya. Metode penelitian yang digunakan pada penelitian ini adalah penelitian penjelasan yang menjelaskan hubungan sebab akibat antara variabel dengan teknik pengumpulan data menggunakan wawancara, observasi, penyebaran kuesioner, dan studi kepustakaan. Penelitian ini menggunakan populasi sebanyak 244 orang. Sedangkan teknik sampling yang digunakan adalah teknik sampling random, dimana sampel diambil dari sebagian populasi yaitu sebanyak 71 orang. Teknik analisa data yang digunakan adalah teknik regresi linier sederhana. Hasil penelitian menunjukkan bahwa Pelaksanaan Pelatihan berpengaruh signifikan terhadap Peningkatan Produktivitas Kerja Karyawan PT. Raya Sugarindo Inti Tasikmalaya, dilihat dari faktor penentu, faktor pengukur dan faktor pengaruh dengan indikatornya adalah pengembangan, penggunaan waktu serta hasil kerja yang dicapai.
\end{abstract}

Kata Kunci : Pelatihan, Produktivitas

\section{Effect Of Training on Employee Productivity at PT. Raya Sugarindo Indo Tasikmalaya}

\begin{abstract}
This study aims to find out the training conducted for employees, employee productivity influence the impact of training on increasing employee productivity, and obstacles faced by PT. Raya Sugarindo Inti Tasikmalaya in conducting training and how to overcome them. The research method used in this research is explanatory research explaining causal relationship between independent variable (training) and dependent variable (work productivity) with data collection technique using interview, observation, spreading of questionnaire, and library study. This study uses a population of 244 people. While the sampling technique used is a random sampling technique, where samples taken from some of the population of 71 people. The results showed that Training Implementation has significant effect on the Increasing Employee Productivity PT. Raya Sugarindo Inti Tasikmalaya, judging from the determinants, the factors of measuring and influencing factors with the indicator is the development, use of time and the work achieved
\end{abstract}

Kata Kunci: Training, Productivity

How to Cite:

Gumilar, G. (2018). Pengaruh Pelatihan Terhadap Peningkatan Produktivitas Kerja Karyawan PT. Raya Sugarindo Inti Tasikmalaya. Jurnal Ilmiah Manajemen dan Bisnis, 19(1), 55-63. https://doi.org/10.30596/jimb.v19i1.1804. 


\section{PENDAHULUAN}

Di era globalisasi saat ini, persaingan antar perusahaan semakin gencar dan teknologi yang maju menimbulkan tantangan perusahaan untuk melakukan perubahaan pada berbagai aspek dalam pengelolan perusahaan. Menghadapi perubahan dan persaingan baik pada tingkat nasional maupun internasional, maka parakaryawan harus beradaptasi atas perubahan dalam teknologi, seperti munculnya teknologi baru atau metode kerja baru di perusahaan. Situasi seperti ini membuat perusahaan membutuhkan sumber daya manusia yang mempunyai pengetahuan, ketrampilan, kemampuan tinggi dan terlatih yang dapat memfokuskan kemampuan mereka pada tugas dan tanggung jawab untuk kepentingan perusahaan. Dalam persaingan dunia usaha yang semakin ketat dan semakin majunya teknologi, setiap perusahaan dituntut untuk selalu melakukan yang terbaik dalam menjalankan kegiatan usahanya. Sumber Daya Manusia adalah yang menjadi intrumen paling penting di dalam perusahaan. Menurut Marwansyah, (2012) "'sasaran strategis mempunyai implikasi yang terdiri dari fungsi operasional, produksi, finansial, pemasaran, dan sumber daya manusia"", sehingga perusahaan perlu merencanakan sasaran strategisnya, sedangkan menurut Ismail, (2010) sumber daya manusia merupakan elemen utama organisasi dibandingkan dengan elemen lain seperti modal, teknologi, dan uang sebab manusia itu sendiri yang mengendalikan yang lain, sehingga perusahaan mampu bersaing dengan perusahaan lain.

Prajitiasari, (2012) meskipun terdapat peralatan canggih yang dimiliki tetapi tanpa didukung oleh sumber daya manusia yang handal untuk mengoperasionalkan maka hasilnya akan tetap sia-sia. Pelatihan adalah proses pembelajaran keterampilan dasar yang dibutuhkan oleh karyawan baru untuk melaksanakan pekerjaan (Dessler, 2010), sedangkan menurut Fajar dan Al, (2013) pelatihan adalah proses pembelajaran yang ditujukan kepada karyawan agar pelaksanaan pekerjaan memuaskan. Dengan pelatihan perusahaan memperoleh masukan yang baik menghadapi tantangan-tantangan manajemen yang terus berkembang dengan memiliki karyawan yang yang dapat memenuhi penyelesaian masalah yang ada Pelatihan merupakan suatu usaha yang terencana dari perusahaan untuk meningkatkan keterampilan dan kemampuan karyawan. Menurut Hariandja, (2002), alasan diterapkannya pelatihan bagi karyawan adalah pegawai yang baru direkrut sering kali belum memahami secara benar bagaimana melakukan pekerjaan, perubahan-perubahan dalam ling kungan kerja dan tenaga kerja, meningkat kan daya saing perusahaan dan memperbaiki produktivitas karyawan, karyawan menyesuaikan dengan peraturan-peraturan yang ada.

Hasibuan, (2007), mengemukan bahwa Produktivitas kerja didefinisikan perbandingan antara output dengan input, dimana output-nya harus mempunyai nilai tambah dan teknik pengerjaannya yang lebih baik. Selanjutnya Herjanto, (2003) mengemuka kan bahwa produktivitas merupakan ukuran bagaimana baiknya suatu sumber daya diatur dan dimanfaatkan untuk mencapai hasil yang diinginkan. Produktivitas pegawai sangatlah perlu, sebab dengan produktivitas ini akan diketahui seberapa jauh kemampuan pegawai dalam melaksanakan tugas yang dibebankan kepadanya, sehingga diperlukan penentuan kriteria yang jelas dan tertukur serta ditetapkan secara bersama sama yang dijadikan sebagai acuan seperti yang dikemukakan oleh Sinungan, (2005) bahwa pengukuran produktivitas merupakan suatu alat manajemen yang penting disemua tingkatan ekonomi.

Satria dan Kuswara, (2013) menjelaskan bahwa bahwa manajemen sumber daya manusia perlu memperhatikan motivasi, pelatihan dan kompetensi karyawan karena akan mempengaruhi produktivitas karyawan 
baik secara langsung maupun tidak langsung, juga akan mempengaruhi kualitas dan produktivitas.

\section{Bidang usaha perusahaan menurut} anggaran dasarnya adalah industri pembuatan High Fructose dan Dextrose, akan tetapi kegiatan produksi High hanya berjalan untuk beberapa tahun saja, selanjutnya karena mengalami persaingan yang cukup kuat dari gula pasir yang mur ah dikarenakan subsidi pemerintah atau Bulog, kegiatan produksi dibatasi hanya memproduksi Dextrose dan Glucose Syrup, namun kegiatan produksinyapun tidak ber langsung lama atau kurang lancar, sehingga kreditnya pada PT. Bank Bumi Daya pun macet. Untuk meningkatkan kinerja perusahaan dalam pencapaian tu juan perusahaan, organisasi dan uraian jabatan PT. Raya Sugarindo Inti yang berlaku, selain itu perlu disempurnakan dengan berpedoman pada Anggaran Dasar Perusahaan yang telah disesuaikan dengan memperhatikan situasi dan kondisi internal perusahaan maupun eksternal. Mengingat terbatasnya Sumber Daya Manusia dan Dana, maka pengendalian maupun pengelolaan atas perusahaan yang berlokasi di Singaparna- asikmalaya untuk sementara perlu dilakukan terpusat dari kantor Jakarta. Sesuai dengan perkembangan kemampuan perusahaan sebagaian pengendalian dan pengelolaan perusahaan secara bertahap akan dilimpahkan ke Kantor Tasikmalaya. Dalam usahanya untuk meningkatkan produktivitas karyawan perlu sekiranya perusahaan setiap tahunnya selalu mengadakan pelatihan bagi karyawan.

Berdasarkan pengamatan yang dilakukan oleh peneliti masih kurangnya produktivitas, kualitas, perencanaan sumber daya manusia serta moral kerja karyawan yang dihasilkan oleh karyawan PT. Raya Sugarindo Inti Tasikmalaya. Banyak faktor yang menjadi dasar permasalahan ini, salah satunya adalah kurangnya pelaksanaan pelatihan kerja yang diselenggarakan oleh PT. Raya Sugarindo Inti Tasikmalaya.

\section{METODE}

Penelitian yang dilakukan adalah penelitian penjelasan yang menjelaskan hubungan sebab akibat antara variabel independent (pelatihan) dan variabel dependent (produktivitas kerja). Penelitian penjelasan ini menyoroti hubungan antara variabel-variabel penelitian dan menguji hipotesa yang telah dirumuskan. Dengan demikian akan diperoleh kepastian pengaruh pendidikan dan pelatihan terhadap produktivitas kerja secara signifikan. Populasi dalam penelitian ini adalah seluruh karyawan PT. Sugarindo Inti Tasikmalaya yang berjumlah 244 orang. Pada penelitian ini, penulis menetapkan ukuran sampel dengan menggunakan rumus Slovin sebagai berikut:

$$
n=\frac{N}{1+N e^{2}}
$$

Keterangan: n: ukuran sampel, N: ukuran populasi, e : nilai kritis (batas ketelitian)

Untuk populasi sebesar 244 orang karyawan, maka nilai kritis atau (e) yang ditetapkan sebesar 10\%. Dengan demikian ukuran sampel yang dibutuhkan berdasarkan rumus di atas adalah $224 / 1+224(0,01)^{2}=$ $224 / 1+2,44=224 / 3,44=70,93$ dibulatkan menjadi 71. Jumlah sampel dalam penelitian ini berjumlah 71 orang pegawai PT. Raya Sugarindo Inti Tasikmalaya. Pengolahan data dalam penelitian ini diambil dari jawaban-jawaban responden terhadap pernyataan-pernyataan yang disebarkan. Skala pengukuran variabel yang digunakan adalah Skala Likert dimana setiap pernyataan tersedia lima jawaban, sehingga penelitian ini memakai kuesioner yang menggunakan lima alternatif jawaban sebagai berikut : "Sangat Setuju" dengan skor 5, "Setuju" dengan skor 4, "Ragu-ragu" 
dengan skor 3, "Tidak Setuju" dengan skor 2, dan "Sangat Tidak Setuju" dengan skor 1. : Instrumen penelitian yang baik harus mempunyai dua pengukuran yaitu harus valid (sahih) dan reliabel (handal, konsisten dan stabil). Sedangkan analisis statistik deskriptif bertujuan untuk mendeskripsikan karakteristik responden yang diteliti serta masing-masing variabel. Teknik analisa data yang digunakan adalah analisis regresi linier sederhana.

\section{HASIL}

Hipotesis dalam penelitian ini yaitu Terdapat pengaruh pelatihan terhadap produktivitas kerja karyawan di PT. Raya Sugarindo Inti Tasikmalaya. Sehinga diperoleh hasil perhitungan menggunakan SPSS seperti terlihat pada Tabel 1.

Tabel 1. Hasil Regresi Linier Sederhana

\begin{tabular}{cccccccc}
\hline & & \multicolumn{2}{c}{$\begin{array}{c}\text { Unstandardized } \\
\text { Coefficients }\end{array}$} & \multicolumn{2}{c}{$\begin{array}{c}\text { Standardized } \\
\text { Coefficients }\end{array}$} & & \\
\cline { 2 - 5 } & Model & B & Std. Error & Beta & & t & Sig. \\
\hline 1 & (Constant) & 54.092 & 6.881 & & & 7.861 & .000 \\
& pelatihan & .440 & .066 & & .625 & 6.654 & .000 \\
\hline
\end{tabular}

a. Dependent Variable: produktivitas kinerja karyawan

Pada Tabel 1 terlihat bahwa kedua hubungan variabel Pelatihan karyawan dan Produktivitas kerja karyawan memiliki persamaan regresi $\mathrm{Y}=54,092+0,440 \mathrm{X}$. Persamaan tersebut dapat dijadikan sebagai perumusan untuk menentukan nilai perubahan kedua variabel tersebut. Kemudian dapat ditafsirkan bahwa semakin sering dilaksanakan pelatihan karyawan, maka produktivitas kerja karyawanpun juga akan meningkat, begitu juga sebaliknya. Dengan demikian dapat disimpulkan bahwa Pelaksanaan Pelatihan untuk karyawan memberikan pengaruh yang signifikan terhadap produktivitas kinerja karyawan di PT. Sugarindo Inti Tasikmalaya.

Untuk menguji kelayakan model dalam persamaan regresi digunakan uji $\mathrm{F}$, dapat diperoleh gambaran adanya ketergantungan variabel dependen terhadap variabel independen. Hal tersebut dapat diasumsikan atau diprediksikan jika variabel independen berubah, maka variabel dependen pun akan berubah sebesar pengaruhnya dan memenuhi persamaan regresi yang sesuai seperti pada Tabel 2.

Tabel 2. Uji kelayakan Persamaan Regresi ANOVA $^{a}$

\begin{tabular}{llrrrrr}
\hline Model & & Sum of Squares & df & Mean Square & F & Sig. \\
\hline 1 & Regression & 115.136 & 1 & 115.136 & 44.270 & $.000^{6}$ \\
& Residual & 179.455 & 69 & 2.601 & & \\
& Total & 294.592 & 70 & & & \\
\hline
\end{tabular}

a. Dependent Variable: produktivitas kinerja karyawan

b. Predictors: (Constant), pelatihan

Tabel 2 menunjukkkan bahwa nilai $\mathrm{F}$ hitung sebesar dengan nilai signifikansi 0,000 yang kurang dari 0,05 maka dapat disimpulkan bahwa model regresi yang akan digunakan sudah layak untuk memprediksi pelaksanaan pelatihan memiliki pengaruh serta saling ketergantungan yang erat dengan Produktivitas kerja. Artinya jika salah satu variabel tersebut berubah, maka variabel yang lainya pun akan berubah. Sehingga apabila pelatihan sering dilakasanakan maka dapat diprediksi bahwa produktivitas kerja karyawan di PT. Sugarindo Inti Tasikmalaya juga mening- 


\section{Published April 2018 \\ JURNAL ILMIAH MANAJEMEN dan BISNIS \\ ISSN 1693-7619 (print) | ISSN 2580-4170 (online), http://jurnal.umsu.ac.id/index.php/mbisnis}

kat. Selanjutnya dilakukan pengujian hipotesis menggunakan uji t untuk melihat apakah variabel pelatiah berpengaruh terahdap produktivitas kerja karyawan, pada Tabel 1 memperlihatkan kolom $\mathrm{t}$ diperoleh nilai 6,654 , sehingga dapat ditarik kesimpulan jika $t_{\text {hitung }}>t_{\text {tabel }}$ maka hipotesis diterima begitu juga sebaliknya jika $t_{\text {hitung }}<\mathrm{t}_{\text {tabel }}$ maka hipotesis ditolak. Pada penelitian ini diketahui $t_{\text {hitung }}$ sebesar $6.654>1.66724\left(\mathrm{t}_{\text {tabel }}\right)$, maka hipotesis diterima, dengan demikian pelatihan memiliki pengaruh terhadap produktivitas karyawan, artinya dengan meningkatkan pelatihan di dalam perusahaan sesuai dengan bidang atau departemen yang ada didalam perusahaan maka produktivitas kerja akan meningkat.

Untuk melihat kontribusi pelatihan terhadap produktivitas, dapat ditentukan melihat koefisien determinasi $\left(\mathrm{R}^{2}\right)$, pada Tabel 3 memperlihatkan bahwa koefisien derterminasi sebesar 0,391 atau 39,1\% pelatihan karyawan mempengaruhi produktivitas kerja karyawan PT. Sugarindo inti Tasikmalaya selebihnya ada factor lain sekitar 60,9\% yang mempengaruhi produktivitas kerja karyawan PT. Sugarindo inti Tasikmalaya di luar pelatihan.

Tabel 3. Hasil Koefisien Determinasi

\begin{tabular}{cccccc}
\hline Model & $\mathrm{R}$ & $\mathrm{R}$ Square & $\begin{array}{c}\text { Adjusted } \\
\mathrm{R} \text { Square }\end{array}$ & $\begin{array}{c}\text { Std. Error of the } \\
\text { Estimate }\end{array}$ & $\begin{array}{c}\text { R Square } \\
\text { Change }\end{array}$ \\
\hline 1 & $.625^{\mathrm{a}}$ & $.625^{\mathrm{a}}$ & .382 & 1.613 & .391 \\
\hline
\end{tabular}

Untuk mengetahui kuat tidaknya hubungan antar kedua variable penelitian, maka dapat dilakukan perhitungan menggunakan korelasi seperti pada Tabel 4.

Tabel 4. Hasil korelasi variabel Correlations

\begin{tabular}{llrr}
\hline & & \multicolumn{1}{c}{$\begin{array}{c}\text { produktivitas } \\
\text { kinerja karyawan }\end{array}$} & pelatihan \\
\hline Pearson Correlation & $\begin{array}{l}\text { produktivitas kinerja } \\
\text { karyawan }\end{array}$ & 1.000 & .625 \\
pelatihan & & .625 & 1.000 \\
Sig. (1-tailed) & $\begin{array}{l}\text { produktivitas kinerja } \\
\text { karyawan } \\
\text { pelatihan } \\
\text { produktivitas kinerja }\end{array}$ & .000 \\
& $\begin{array}{l}\text { karyawan } \\
\text { pelatihan }\end{array}$ & 71 & 71 \\
& & 71 & 71 \\
\hline
\end{tabular}

Pada Tabel 4 diperoleh koefisien Korelasi sebesar 0,625 yang berarti Pelaksanaan Pelatihan karyawan mempunyai pengaruh signifikan terhadap produktivitas kerja karyawan PT. Sugarindo inti Tasikmalaya dan termasuk kategori Kuat. Sedangkan untuk mengetahui klasifikasi penilaian pelatihan menentukan intervalnya dengan menggunakan rumus sebagai berikut:

$$
N J I=\frac{\text { Nilai tertinggi }- \text { Nilai terendah }}{\text { Jumlah } \text { kriteria pertanyaan }}
$$

Keterangan: NJI : Nilai Jenjang Interval

Dimana NJI adalah interval untuk menentukan kriteria sangat baik, baik, cukup, kurang, sangat kurang, dari suatu interval. Jumlah kriteria pernyataan: Nilai tertinggi secara keseluruhan $=71 \times 5 \times 25$ $=8875$, Nilai terendah secara keseluruhan $=$ 71 × 1 x $25=1775$, Dengan demikian interval yang diperlukan untuk memperoleh klasifikasi penilaiannya adalah:

$$
N J I=\frac{8875-1775}{5}=1420
$$


Sehingga kriteria klasifikasi penilaian skor hasil penelitian adalah nilai 1775 3195 (sangat kurang), 3195 - 4615 (Kurang), 4615 - 6035 (Cukup), 6035 7455 (Baik), 7455 - 8875 (Sangat baik). Berdasarkan rekapitulasi jawaban mengenai pelaksanaan pelatihan kerja karyawan PT. Raya Sugarindo Inti Tasikmalaya diperoleh jumlah skor sebesar 7390 dan berada pada interval 6035 - 7455, yang menunjukan klasifikasi baik. Hal ini berarti bahwa program pelatihan yang diikuti karyawan berjalan dengan baik , terencana dan berkesinambungan.

\section{PEMBAHASAN}

Dengan adanya pelaksanaan pelatihan, diharapkan pekerjaan dapat terselesaikan secara efektif dan efisien. Pelatihan adalah proses mengajarkan karyawan baru atau karyawan lama. Untuk karyawan lama bertujuan untuk memperbaiki kinerja yang kurang baik, mempelajari pengetahuan dan teknologi, serta keterampilan yang baru untuk mempelajari pengetahuan dan teknologi serta keterampilan yang baru juga untuk menyesuaikan dengan perkembangan organisasi dan kebijakan organisasi yang baru. Sedangkan bagi karyawan baru akan memberikan keterampilan dasar yang dibutuhkan untuk menjalankan pekerjaannya.

ElObeidy, (2016) menyatakan bahwa perhatian yang lebih besar harus diberikan pada pelatihan kerja dan pendidikan seumur hidup. Pendidikan kejuruan dan pelatihan kerja telah menjadi bagian integral dari strategi pembangunan nasional di banyak masyarakat karena dampaknya terhadap produktivitas sumber daya manusia dan pertumbuhan ekonomi. Penyelenggaraan pelatihan bagi karyawan PT. Raya Sugarindo Inti Tasikmalaya memiliki manfaat yang besar bagi perkembangan kemampuan karyawan dalam mengerjakan tugas dan tanggung jawabnya. Dengan pelaksanaan pelatihan akan meningkatkan produktivitas kerja, yang juga dikarenakan para karyawan telah telah memiliki modal atau kemampuan yang cukup untuk mencapai tujuan perusahaan.

Selanjutnya Produktivitas kerja merupakan salah satu indikator pengukuran keberhasilan manajer sumber daya manusia untuk mencapai tujuan yang telah ditetapkan. Adapun pendapat lain yang dikemukakan oleh Guerrazzi, (2016) mengemukakan bahwa Produktivitas perusahaan tergantung pada cara negatif pada persentase perempuan yang dipekerjakan. Temuan ini secara statistik signifikan dan mengungkapkan bahwa perusahaan dengan sejumlah besar perempuan mengalami kesenjangan produktivitas sehubungan dengan unit produktif di mana jumlah laki-laki lebih tinggi. Pola ini mungkin disebabkan oleh masalah rekonsiliasi yang biasanya menyebabkan perempuan terlalu terwakili dalam pekerjaan paruh waktu. Pimpinan dan karyawan memerlukan umpan balik atas kerja keras mereka dalam rangka mencapai suatu tujuan maupun sasaran kerja. Hal ini pula yang dilaksanakan oleh PT. Raya Sugarindo Inti Tasikmalaya dimana produktivitas kerja menjadi salah satu indikator dalam pencapaian tujuan organisasi. Hal ini dilakukan dengan melakukan pelatihan, sehingga dengan adanya pelatihan diharapkan produktivitas kerja karyawan dapat meningkat.

Berdasarkan hasil penelitian diketahui bahwa variabel Pendidikan dan Pelatihan pada karyawan berpengaruh signifikan terhadap Produktivitas Kerja sesuai dengan penelitian yang dilakukan oleh Prajitiasari, (2012) Pendidikan dan latihan dapat meningkatkan produktivitas kerja dalam kuantitas maupun kualitas. Di satu sisi, angka-angka dari regresi tahap pertama menunjukkan bahwa ada hubungan yang cukup kuat di antara dua ukuran penyediaan pelatihan dan sebagian besar regresi yang digunakan. Terdapat dua hasil sangat luar biasa, yaitu pertama, penyediaan pelatihan di sepanjang kedua margin sangat terkait dengan jumlah pekerja yang digunakan dari 
kekuatan instrumen yang dipilih, perusahaan yang lebih besar cenderung lebih rentan terhadap pasokan pelatihan sehubungan dengan usaha yang lebih kecil. Adapun rasionalisasi yang mendasari efek ukuran mikroekonomi ini ditemukan dalam fitur yang menjadi ciri investasi pengeluaran dalam perusahaan yang lebih besar, yaitu skala ekonomi dalam penyediaan pelatihan formal dan informal (Black et al., (1999) dan akses yang lebih baik dan lebih murah ke pasar modal untuk membiayai investasi dalam modal manusia (Hashimoto, 1979). Selain itu, efek marjinal terkuat pada dua ukuran penyediaan pelatihan didorong oleh investasi R\&D. Bahkan temuan ini jauh dari mengejutkan, yakni sejumlah penulis secara meyakinkan berpendapat bahwa penge luaran R\&D secara ketat terhubung dengan biaya pelatihan untuk tenaga kerja yang dipekerjakan (Cohen dan Levinthal, (1989), kecakapan yang lebih tinggi dapat meningkatkan hasil dan dapat menghasilkan kualitas yang baik.

Berdasarkan tabel rekapitulasi jawaban mengenai peningkatan produktivitas kerja karyawan PT. Raya Sugarindo Inti Tasikmalaya diperoleh jumlah skor sebesar 7090 dan berada pada interval 6035 - 7455, yang menunjukan klasifikasi baik. Hal ini didapat dari peningkatan produktivitas kerja karyawan yang dicapai setelah mengikuti pelatihan. Yang menjadi perhatian penting dalam pelatihan manajemen dan program pengembangan adalah adanya diagnosis dan identifikasi keadaan pengembangan manajerial dalam suatu organisasi, hal ini bertujuan untuk meng efektifkan program pengembangan dan pelatihan yang dilaksanakan serta menetukan tingkat pengembalian investasi dalam pelatihan manajemen dan program pengembangan(Alan et al., 2011); Bartel (1994); Menon, (2013) mengemukakan bahwa terdapat hubungan yang kuat antara pelatihan tenaga kerja yang dilaksanakan dengan produktivitas pekerja. Ketika perusahaan menawarkan program pelatihan terhadap karyawan, maka karyawan mendapatkan motivasi yang tinggi dan mengerahkan segenap kemampuan yang dimiliki yang dapat diterjemahkan dengan output yang lebih tinggi (Bose dan Gupta, 2012), pernyataan yang serupa yang dikemukakan oleh Triasmoko, (2014) mengemukakan bahwa pelatihan kerja karyawan sangat diperlukan dalam mengembangkan ketrampilan dari diri karyawan itu sendiri, terutama kinerja karyawan bertujuan agar lebih meningkatkan standart yang ditetapkan oleh perusahaan. Sementara hasil penelitian Siswadi, (2016); Abomeh dan Peace, (2015) menyebutkan ada pengaruh yang signifikan antara pelatihan dan produktivitas kerja karyawan.

\section{SIMPULAN}

Variabel Pelatihan secara parsial mempengaruhi Produktivitas Kerja. Hal ini berarti terdapat hubungan yang nyata antara Pelatihan terhadap Produktivitas Kerja. Pelatihan berdampak positif terhadap peningkatan produktivitas. Agar perusahaan dapat beradaptasi dan menselaraskan tuntutan pelanggan pengguna produk/jasa perusahaan dan kemajuan ilmu pengetahuan, teknologi, dan informasi dengan kemampuan sumber daya manusia yang dimiliki perusahaan maka praktek training dan pelatihan harus dapat dilakukan secara berkala sehingga kemampuan dan keterampilan karyawan dapat selalu meng-upgrade untuk disesuaikan dengan tuntutan pelanggan pengguna produk/jasa perusahaan dan kemajuan ilmu pengetahuan, teknologi, dan informasi. Setelah merencanakan, melaksanakan, melakukan evaluasi terhadap hasil training maka manajemen perlu menjamin bahwa distribusi training harus dilakukan secara adil kepada seluruh karyawan, dengan pertimbangan bahwa karyawan sangat membutuhkan praktik tersebut. Hal ini penting untuk menjamin pemerataan kemampuan dan keterampilan. Meskipun 


\section{Published April 2018 \\ JURNAL ILMIAH MANAJEMEN dan BISNIS \\ ISSN 1693-7619 (print) | ISSN 2580-4170 (online), http://jurnal.umsu.ac.id/index.php/mbisnis}

demikian, bukan berarti bahwa seluruh karyawan harus memperoleh materi training yang sama karena dapat menelan biaya yang sangat besar. Hal ini dapat disiasati dengan membagi-bagi materi training, artinya tiap karyawan menerima materi training yang berbeda disesuaikan dengan kebutuhannya. Selanjutnya adalah menjadi tugas manajemen untuk menjamin terjadinya transfer kemampuan dan keterampilan kepada karyawan lain.

\section{REFERENSI}

Abomeh, O. S., \& Peace, N.K. (2015). Effects of Training on Employees' Productivity in Nigeria Insurance Industry. British Journal of Economics, Management \& Trade, 7(3), 227-235.

Alan, M. S., Tamkin, P., \& Luis, P. (2011). Management training and development. International Journal of Training and Development, 15(3), 179-183.

Bose, A., \& Gupta, G. (2012). Optimal Training, Employee Preferences and Moral Hazard. Journal of Economic and Social Development, 1(1, 1-24.

Bartel, A.P. (1994). Productivity gains from the implementation of employee training Programs. Industrial Relations A Journal of Economy And Society, 33(4). 411-425.

Black, D. A., Noel, B.J. and Wang, Z. (1999). On-The-Job Training, Establishment Size, And Firm Size: Evidence For Economies Of Scale In The Production Of Human Capital.Southern Economic Journal, 66(1), 82-100.

Cohen, W. M. and Levinthal, D. A. (1989). Innovation and learning: the two faces of R\&D. Economic Journal, 99(397). 569-96.

Dessler, G. (2010). Manajemen Sumber Daya Manusia. Edisi Kesepuluh. Jakarta Barat: PT Indeks.
ElObeidy, A (2016). The role of education and training in enhancing labour productivity in Arab countries in Africa. International journal of training and development, 20(3), 238245.

Fajar, S., \& Al, T. H. (2013). Manajemen Sumberdaya Manusia. Edisi Kedua. Yogyakarta: UPP STIM YKPN

Guerrazzi, M. (2016). The effect of training on Italian firms productivity: microeconomic and macroeconomic perspectives. International journal of training and development,20(1), 3857.

Hariandja, M. T. E. (2002). Manajemen Sumber Daya Manusia. Edisi Pertama. Jakarta: PT Gramedia Widiasarana Indonesia

Hasibuan, M. S. P. (2007). Manajemen sumber Daya Manusia. Jakarta: Bumi Aksara

Hashimoto, M. (1979). Bonus payments, onthe-job training, and lifetime employment in Japan. Journal of Political Economy, 87(5), 1086-104.

Herjanto, E. (2003). Manajemen Produksi dan Operasi. Jakarta: Gramedia

Ismail, I. (2010). Manajemen Sumber Daya Manusia. Edisi Pertama. Malang: Lembaga Penerbitan Fakultas Pertanian Universitas Brawijaya Malang

Marwansyah. (2012). Manajemen Sumber Daya Manusia. Edisi kedua. Bandung: Alfabeta.

Menon, M. E. (2013). Productivity Gains from Training: The Views of Employers and Stakeholders. Journal of Education and Training Studies, 1(1), 118-128.

Prajitiasari, E. D. (2012). Pengaruh Pendidikan dan Pelatihan Pada Karyawan Terhadap Produktivitas Kerja Pada PT.Bank Rakyat Indonesia (Persero) Cabang Tulung Agung. Jurnal Media Mahardika, 10(2), 1-15. 


\section{JURNAL ILMIAH MANAJEMEN dan BISNIS

Siswadi, Y. (2016). Pengaruh Pelatihan Dan Disiplin Terhadap Produktivitas Kerja Karyawan Padapt. Jasa Marga Cabang (Belmera) Medan. Jurnal Ilmiah Manajemen dan Bisnis 17(1), 124137.

Satria, R. O., \& Kuswara, A. (2013). Pengaruh Motivasi Dan Pelatihan Terhadap Kompetensi Kerja Serta Implikasinya Pada Produktivitas Pegawai Dinas Perhubungan Kota Bandung. Jurnal Ekonomi, Bisnis \& Enterpreneurship, 7(2),74-83.

Sinungan, M. (2005). Produktivitas apa dan bagaimana. Jakarta: Bumi aksara.

Triasmoko, D., \& Al, (2014). Pengaruh Pelatihan Kerja Terhadap Kinerja Karyawan. Jurnal Administrasi Bisnis (JAB), 12(1), 1-10. 